\title{
3D nyomtatható MED610 polimerből kioldódó monomerek kvalitatív analízise és ezek hatása sejtekre
}

\author{
DR. YOUSSEF ADELINA STEPHANIE*, DR. TÓTH FERENC**, \\ DR. HEGEDÜS CSABA**, DR. SZALÓKI MELINDA**
}

\begin{abstract}
A háromdimenziós (3D) nyomtatást, dinamikusan fejlődő technikájának köszönhetően, az ipari területek után az orvostudomány is egyre szélesebb körben alkalmazza. A fogászatban elterjedt 3D nyomtatáshoz használt polimerek orális környezetben való használata során kulcskérdés a biokompatibilitás. Célkitűzésünk a MED610 (Stratasys, USA) polimerből készített mintákból kioldódó komponensek azonosítása, valamint ezek hatásának megfigyelése csont eredetű sejtek osztódására. A kutatás során különböző méretű és felületnagyságú objektumokat nyomtattunk Objet 30 OrthoDesk (Stratasys, USA) nyomtatóval, és felületkezeltük a gyártó utasításai szerint. Ezen minták közvetve vagy közvetlenül érintkeztek Sarcoma Osteogenic-2 (SAOS-2) sejtekkel. A MED610 kioldódási vizsgálatát metanolban végeztük, amit gázkromatográfia-tömegspektrometria kapcsolt módszerrel (GC-MS) analizáltunk. A proliferációra gyakorolt hatásokat alamarBlue assay segítségével mértük. A vizsgálatok alapján izobornil-akrilát, hidroxiciklohexil-fenil-keton és kaprolakton oldódik ki nagyobb mennyiségben a MED610 polimerből. A sejtéletképességi vizsgálatok eredményei alapján pedig elmondható, hogy a MED610 a felületnöveléssel párhuzamosan szignifikánsan csökkenti a SAOS-2 sejtek proliferációját, amelyet az anyaggal történő közvetlen érintkezés felerősít. Az általunk megfigyelt hatást valószínúleg a MED610-ből kioldódó toxikus anyagok okozzák, amelyek a nagyobb felület következtében gyorsabban oldódnak ki, ezáltal nagyobb koncentrációban találhatóak meg a sejtek környezetében.
\end{abstract}

Kulcsszavak: MED610, biokompatibilitás, 3D nyomtatás, SAOS-2, alamarBlue

\section{Bevezetés}

A háromdimenziós $(3 \mathrm{D})$ nyomtatás első ipari alkalmazásai a gyors prototípusgyártás területén voltak, így a fogászatban való felhasználása, ahol egyéni, személyre szabott tárgyakat gyártanak, nyilvánvalóan bekövetkező lépés volt. Manapság, kombinálva a szkennelést, a CAD tervezést (Computer-Aided Design - számítógép támogatott tervezés) és a 3D nyomtatást, a fogászati laboratóriumok képesek pontosan és gyorsan előállítani ideiglenes koronákat, hidakat, modelleket, sebészi vezető lemezeket és fogszabályozó készülékeket. A kényelmetlen lenyomatvétel helyett 3D-s szkennelés történik, amelyet később átalakítanak 3D-s modellé, és elküldik 3D nyomtatásra. A minták tárolhatók digitálisan, 3D CAD fájlként. A 3D nyomtatás lehetővé teszi az egész munkafolyamat digitalizálását, drámaian felgyorsítva a gyártási időt, és szignifikánsan emelve a termelési kapacitást, továbbá lehetővé válik a fizikai lenyomatok és a minták tárolásának megszüntetése [7].

A Stratasys cég által 3D nyomtatásra kínált MED610 anyag a gyártó leírása szerint biokompatibilis. A cég felhasználási útmutatója alapján az anyag bőrrel legfeljebb 30 napig, nyálkahártyával pedig 24 óráig érint- kezhet [13]. A gyártó ezt a rigid és transzparens anyagot elsősorban fogszabályozó készülékek, pozícionáló sínek, valamint mútéti sablonok készítéséhez ajánlja [3, $8,14,24,25]$. A Stratasys utasításai szerint felületkezelt anyagot a DIN EN ISO 10993.1: 2009 szabvány alapján biokompatibilitási szempontból elfogadhatónak ítélték. Ezek a vizsgálatok a citotoxicitást, a genotoxicitást, a késleltetett túlérzékenységet és a VI. osztályú USP müanyag-osztályozást érintik, amelyek magukban foglalják az irritációt, az akut szisztémás toxicitást és a beültetést. Ugyanakkor a Stratasys által kiadott „Biokompatibilitási követelmények” anyagában a dokumentum végén található nyilatkozatban a cég egyértelmúvé teszi, hogy kizárólag az ügyfeleik és gépeik végfelhasználóinak a felelőssége meghatározni a nyomtatott tárgyak biokompatibilitását a saját, egyéni felhasználásuknak megfelelően [11].

Jóllehet a MED610 ígéretesnek tűnő biokompatibilis anyag, ugyanakkor viszonylag kevés és ellentmondásos független vizsgálaton esett át [10]. Egyes vizsgálatokban a kutatók nem találtak eltérést a MED610-ből készült eszközök és a kontrollként alkalmazott eszközök szövetekre gyakorolt hatása között [20, 26], ugyanakkor más kísérletek során annak negatív hatása 
igazolódott [22]. Továbbá a felületkezelés hiányában bekövetkező káros hatásokat mutattak ki Macdonald és munkatársainak eredményei [17].

A SAOS-2 sejtek az oszteoblasztokhoz hasonló jellemzőkkel rendelkeznek [5, 21], ezenkívül könnyen és hosszú időn át fenntarthatóak és tenyészthetőek, a velük végzett kísérletek eredményei könnyen reprodukálhatóak, valamint igen elterjedtek a csonttal kapcsolatos kutatásokban, így ideális sejtvonal volt a vizsgálatainkhoz. Mivel a MED610 felhasználása során érintkezhet csont típusú sejtekkel, a SAOS-2 sejtvonal segítségével információt kaphatunk arról, hogyan befolyásolhatja a MED610 anyag a vele kapcsolatban lévő sejtek életképességét.

Jelen munkánk célja az volt, hogy meghatározzuk a MED610 polimerből kioldódó komponenseket, valamint azok sejtéletképességre kifejtett hatását Sarcoma Osteogenic-2 (SAOS-2) sejteken. Továbbá, vizsgáltuk a felületkezelés hatására bekövetkező változásokat is a fent leírt folyamatokban.

\section{Vizsgálati anyag és módszer}

\section{D nyomtatás}

MED610 (Stratasys, USA) modell anyagból Objet 30 OrthoDesk típusú PolyJet 3D nyomtató (Stratasys, USA) segítségével különböző méretü, formájú és felületnagyságú objektumokat nyomtattunk, amelyeket előzőleg az Objet Studio (Tri-Tech 3D, Egyesült Királyság) program segítségével terveztünk meg. A kísérletek elvégzéséhez $5 \mathrm{~mm} \times 7,84 \mathrm{~mm}$ dimenziójú hengerek, valamint $14 \mathrm{~mm} \times 1 \mathrm{~mm}$-es korongok készültek.

\section{Felületkezelés}

A támaszanyagot a gyártó utasításainak megfelelően eltávolítottuk. Ez többlépéses tisztítási folyamatból állt. Első lépésben a támaszanyag mechanikai eltávolítása történt WaterJet (Stratasys, Izrael) vízborotva alkalmazásával. A felületkezeléshez először nátriumhidroxid granulátumból (VWR, Magyarország) készült 1 tömegszázalékos ( $\mathrm{m} / \mathrm{m} \%)$ oldatában három órán keresztül voltak áztatva a MED610-ből készített tárgyak. Ezt 30 perces izopropanolban (VWR, Magyarország) való áztatás követte, majd két órán keresztül száradtak egy lamináris bokszban. Ezek után a tárgyakat autoklávban sterilizáltuk $121^{\circ} \mathrm{C}$-on, 1,1 bar nyomáson.

\section{Sejtéletképességi vizsgálatok}

A sejtéletképességi kísérleteket Sarcoma Osteogenic-2 (SAOS-2) sejtvonalon végeztük. A sejteket $10 \%$ fetal bovine serum-ot (Gibco, Dél-Amerika), 1\% Antibiotic-Antimycotic (Gibco, USA) oldatot, valamint 1\% Glutamaxot (Gibco, Japán) tartalmazó Dulbecco's Modified Eagle's Medium - low glucose (Sigma-Aldrich, USA) médiumban növesztettük $37^{\circ} \mathrm{C}$-on, $5 \%$-os $\mathrm{CO}_{2}$ tartalom mellett.

A kísérletek során megvizsgáltuk a sejtek közvetlen és közvetett érintkezését a MED610 anyaggal, valamint

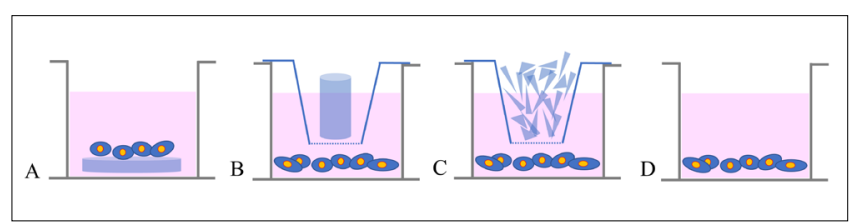

1. kép: Kísérleti elrendezések.

A: MED610 korong közvetlen érintkezése a sejtekkel,

$B$ : MED610 henger közvetett érintkezése a sejtekkel,

C: felületnövelt (összetört) MED610 henger közvetett érintkezése a sejtekkel, D: kontroll

a különböző felületnagyságok sejtéletképességre gyakorolt hatását. (1. kép)

A közvetlen érintkezéshez MED610 anyagból nyomtatott korongokat $(14 \mathrm{~mm} \times 1 \mathrm{~mm}$ ) helyeztünk a sejttenyésztő lemez lyukaiba, amihez közvetlenül tapadhattak ki a sejtek. (2. kép)

A közvetett érintkezés vizsgálatához $8 \mu \mathrm{m}$ pórusméretű Millicell inzertekbe (Merck, Németország) helyeztük a MED610 anyagból készült hengereket (5 mm $\times 7,84 \mathrm{~mm}$ ), melyek térfogata megegyezett a közvetlen érintkezés elemzésénél felhasznált korongokéval. (3. kép)

A megnövelt felületnagyság hatásának vizsgálatához $5 \mathrm{~mm} \times 7,84 \mathrm{~mm}$ dimenziójú hengereket használtunk, melyek ép és összetört (felületnövelt) változatát (4. kép) helyeztük a Millicell inzertekbe. A felületnöveléshez a hengereket dörzsmozsárban törtük össze, és 0,3 gokat helyeztünk az inzertekbe.

A vizsgálatban választott kontrollt a MED610 mintával semmilyen formában nem érintkező SAOS-2 sejtek jelentették.

A vizsgálatokhoz $10^{5} \mathrm{db}$ sejtet ültettünk ki 24 lyukú sejttenyésztő edény megfelelő számú lyukába, majd 1, 4 és 7 nap után alamarBlue assay (Thermo Fisher Scientific, USA) valamint Hidex Sense mikroplate olvasó (Hidex, Finnország) segítségével határoztuk meg az élő sejtek mennyiségeit. Zeiss Axio Vert.A1 fénymikroszkóppal (Zeiss, Németország) folyamatosan tanulmányoztuk a sejtek alakját, elhelyezkedését, sűrǔségét, amelyeket Zen lite program (Zeiss, Németország) használatával dokumentáltunk. A kísérleteket három párhuzamos mintával végeztük, és minden minta három technikai ismétléssel került lemérésre.

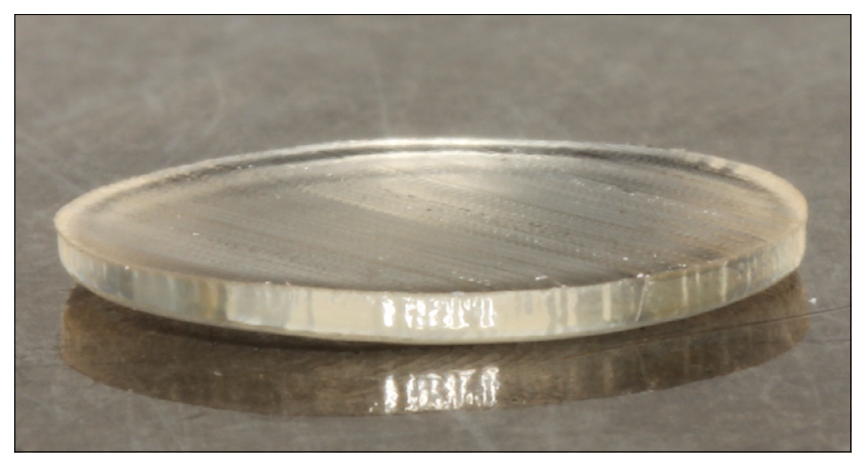

2. kép: MED610-ből nyomtatott korong 


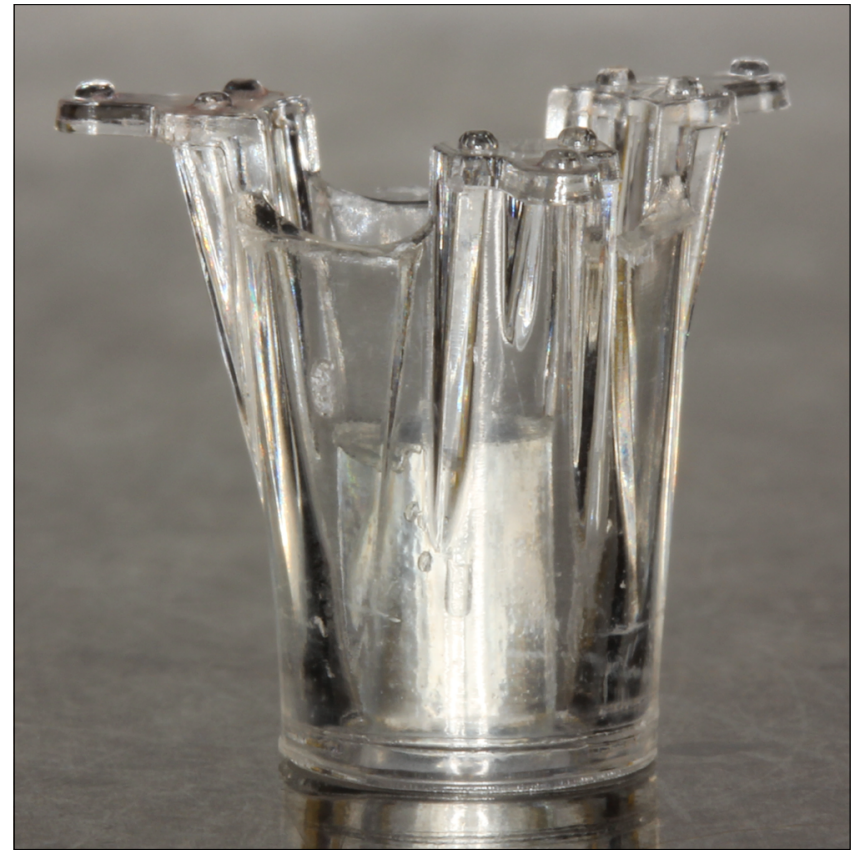

3. kép: Millicell inzertbe helyezett MED610-ből nyomtatott henger

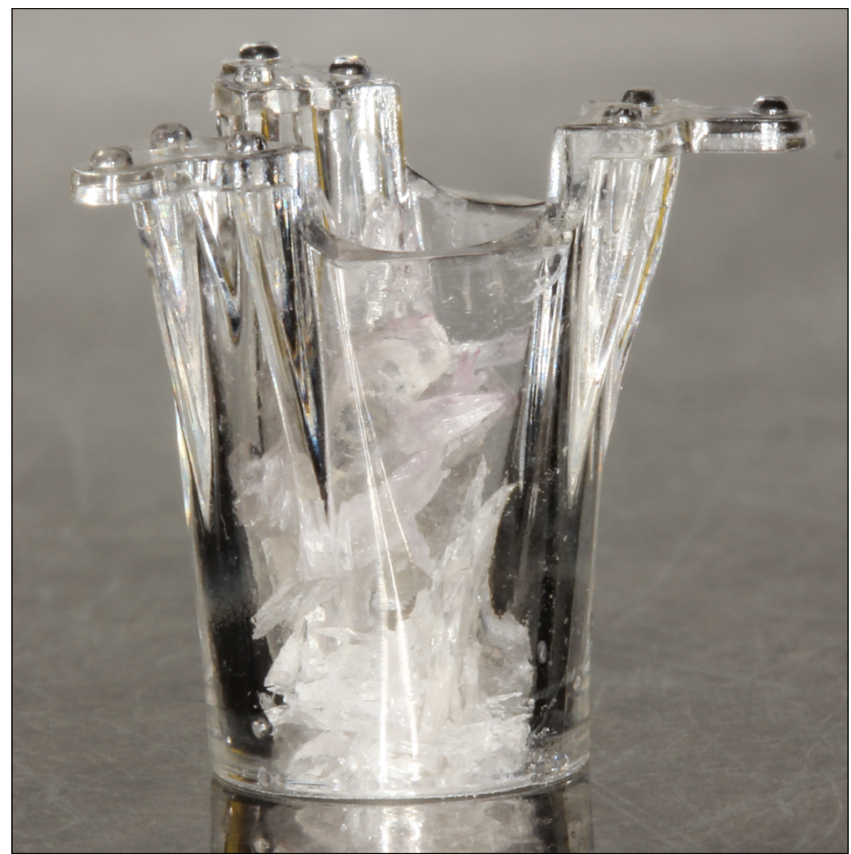

4. kép: Millicell inzertbe helyezett MED610-ből nyomtatott összetört henger

\section{Eredmények}

A MED610 anyagból nyomtatott korongok $(14 \mathrm{~mm} \times$ $1 \mathrm{~mm}, \mathrm{n}=3$ ) kioldódás-vizsgálata metanolban (VWR, Magyarország), toluol belső standard (VWR, Magyarország) hozzáadásával történt és gázkromatográfiatömegspektrometria kapcsolt módszerrel (GC-MS) analizáltuk. A gázkromatográf GC-2010 (Shimadzu, Japán), a tömegspektrométer pedig GCMS-QP2010 Plus (Schimadzu, Japán) típusú volt. A kioldó közeg a metanol volt, mert ez a várható kioldódó komponensek jó oldószere. A vizsgálat fő célja a kioldódó komponensek azonosítása, nem az anyag szervezetben való viselkedésének modellezése volt. A kioldó közeg $25 \mathrm{ml}$ metanol és $25 \mu$ toluol elegye volt, a koncentráció gradiens kialakulásának megakadályozása érdekében a kioldó közeget folyamatosan kevertettük a vizsgálati idő alatt. A mintavételeket 30 perc, 1 óra, 2 óra, 4 óra, 8 óra, 12 óra, 24 óra, 48 óra, 4 nap és 7 nap inkubáció után végeztük el. Mintavétel után a mintákat lezárva tároltuk $4{ }^{\circ} \mathrm{C}$-on a mérésig. A komponenseket spektrumkönyvtár segítségével összehasonlítás alapján azonosítottuk (NIST05s adatbázis).

\section{Statisztikai elemzés}

Az alamarBlue eredményeinek statisztikai elemzése az Excel Analysis Toolpack (Microsoft, USA) programjával történt. Az elemzés során először F-próba segítségével vizsgáltuk a minták varianciáinak egyezőségét. Egyező varianciák esetén klasszikus kétmintás T-próba segítségével határoztuk meg a minták közötti különbségek szignifikáns vagy nem szignifikáns voltát. Eltérő varianciák esetén ugyanezt a Welch-féle T-próba segítségével vizsgáltuk. A választott szignifikanciaszint 0,05 volt.

\section{Közvetett és közvetlen érintkezés hatása a sejtek életképességére}

A MED610 3D modell anyaggal közvetett és közvetlen módon érintkező SAOS-2 sejtek sejtéletképességi eredményeit az 5. kép mutatja be. A közvetett érintkezés esetén az inkubáció negyedik és hetedik napján szignifikáns csökkenést tapasztaltunk a kontrollsejtek proliferációjához képest. Az anyaggal közvetlenül érintkező sejtek száma szignifikánsan lecsökkent mind a kontrollhoz, mind az anyaggal csak közvetetten érintkező sejtek mennyiségéhez képest, az 1., 4. és 7 . napon egyaránt. (5. kép)

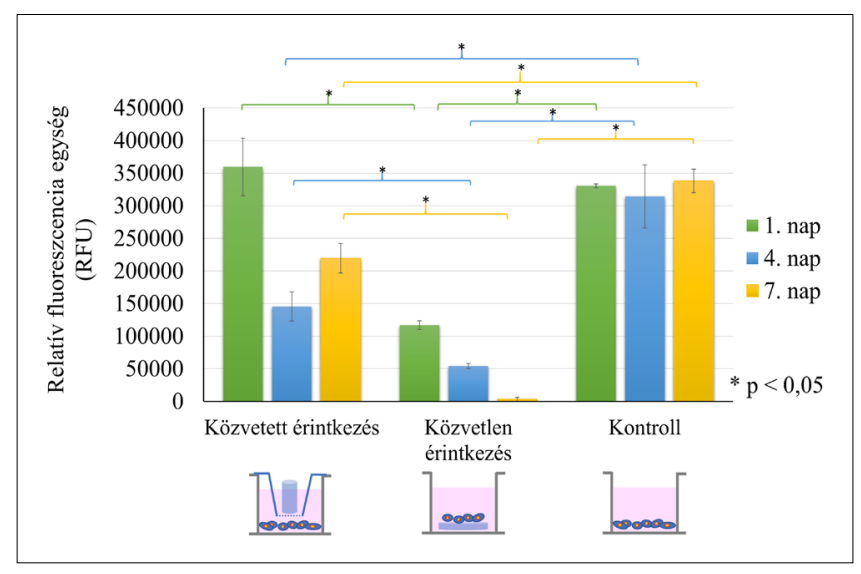

5. kép: MED610 3D nyomtatható polimer hatása a sejtszámra SAOS-2 sejtekkel

közvetett és közvetlen módón történő érintkezés során. A kontroll a mintát nem tartalmazó SAOS-2 sejtek ugyanazon összetételü médiumban. 


\section{A felületnagyság növelésének hatása a sejtek életképességére}

A 6. kép mutatja a megnövelt felületű MED610 hatásának vizsgálati eredményeit SAOS-2 sejtvonalon. Az ép és a - felületnövelés céljából - összetört hengereket tartalmazó lyukakban lévő sejtek osztódási gyakoriságának összehasonlításakor megállapítható, hogy a megnövelt felületű MED610 szignifikánsan csökkentette a sejtszámot az ép, kisebb felületnagyságú anyagot tartalmazó lyukakban mért értékekhez képest, a vizsgálati időpontok mindegyikében. Ép henger esetén szignifikáns csökkenés a 4. és 7 . napon, míg a felületnövelt henger esetében mind az 1., 4. és a 7. napon is szignifikáns csökkenés volt tapasztalható a kontrollsejtek proliferációjához képest.

\section{Mikroszkópos felvételek}

A sejttenyésztő edényekben lévő élő sejtekről reprezentatív mikroszkópos felvételeket mutat be a 7. kép. Ezeken a képeken megfigyelhetők a sejtszámbeli eltérések, amelyek megerősítik az alamarBlue assay során mért értékeket. A látómezőben lefotózott sejtek képei alapján jól megfigyelhető, hogy a felületnövelt MED610 hengerekkel közvetett módon kapcsolatba kerülő sejtek száma csökkent (7.B), az ép, MED610 hengerrel közvetetten érintkező sejtek (7.A) számához képest. A kontrollsejtekhez viszonyítva (7.C) szembetűnő a sejtszámbeli csökkenés mind a 4. és a 7. napon az ép MED610 hengert tartalmazó mintákhoz képest (7.A). Az összetört (felületnövelt) MED610 hengerrel közvetve érintkező sejtek (7.B) esetében mind az 1., 4. és a 7 . napon is jelentős volt a sejtszámbeli eltérés a kontrollhoz viszonyítva (7.C). A MED610 korongokkal közvetlenül érintkező sejtekről nem volt készíthető mikroszkópos kép, mert az anyag nem transzparens, és csak korlátozottan átvilágítható.

\section{Kioldódási vizsgálatok}

Kísérletünk során a kioldódási vizsgálat fő célja a kioldódó komponensek minőségi meghatározása volt, valamint ezen anyagok detektált jeleire vonatkoztatott relatív csúcs alatti területek időbeni változási tendenciájának a megfigyelése. A kioldódási vizsgálat eredményei alapján több komponens is azonosításra került, három közülük a kromatogramon megjelenő viszonylag nagy intenzitásokkal. Ezek a spektrum könyvtárakkal hasonlósági vizsgálatok alapján történt azonosítások szerint az izobornil-akrilát, hidroxiciklohexil-fenil-keton (Irgacure184) és az $\varepsilon$-kaprolakton voltak. Az izobornil-akrilát 30,22-es, a hidroxiciklohexil-fenil-keton 20,79 -es, az $\varepsilon$-kaprolakton pedig 25,31-es retenciós idővel jelentek meg a kromatogramon. A hasonlósági index $88 \%$ volt az izobornilakrilát esetén, $91 \%$ a hidroxiciklohexil-fenil-keton (Irgacure184), valamint 90\% a kaprolakton esetében. Ezek alapján elmondható, hogy a mért tömegspektrumok jó egyezést mutattak a könyvtári spektrumokkal.

A komponensek kioldódási profilját ismerteti a 8. kép. A kioldódási görbékből látható, hogy a vizsgált komponensek telítési görbét adtak a 7 napos kioldódási vizsgá-

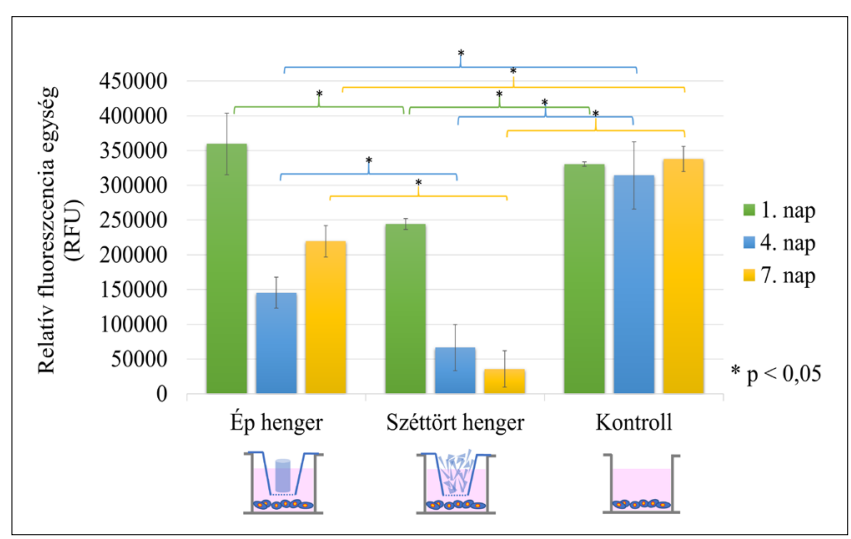

6. kép: MED610 3D nyomtatható polimer felületnagyság növelésének hatása SAOS-2 sejtek életképességére

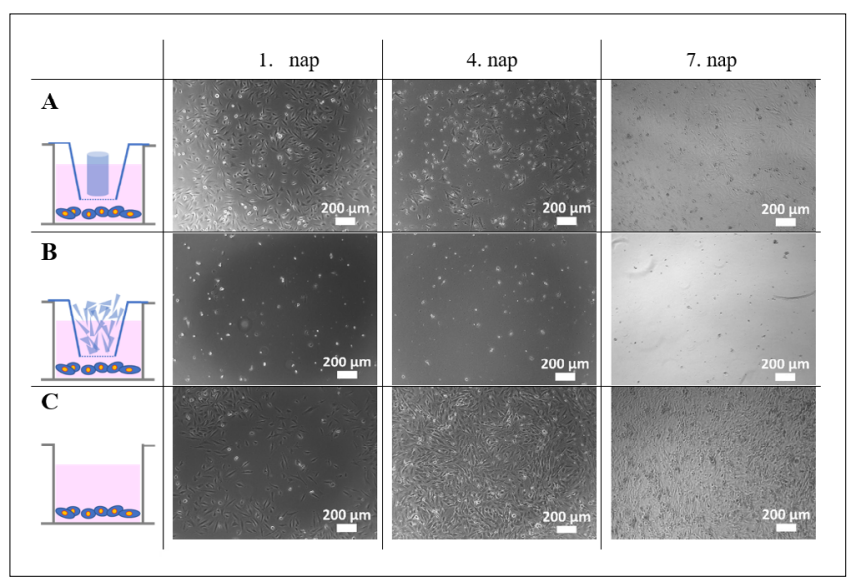

7. kép: Az egyes mintákkal érintkező SAOS-2 sejtekről készült reprezentatív mikroszkópos felvételek

A: ép MED610 henger közvetett hatása $8 \mu \mathrm{m}$-es pórusátmérőjü inzertbe helyezve,

B: felületnövelt (összetört) MED610 henger hatása $8 \mu$ m-es pórusátmérőjü inzertbe helyezve, C: Kontroll

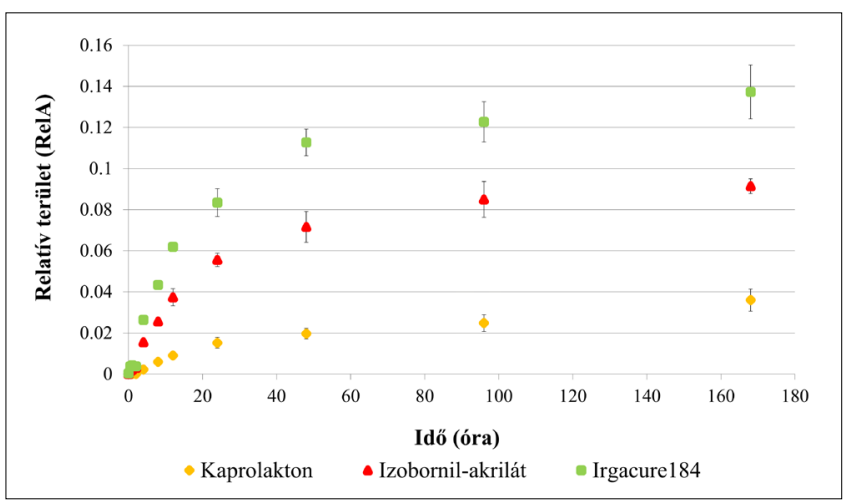

8. kép: A MED610 anyagból kioldódó komponensek kioldódási profilja

lati periódus alatt, amiből megállapítható, hogy azok jelentős része kioldódott, a kioldódás sebessége folyamatosan csökkent a 7 . nap végéig. A relatív területek (RelA) 
kiszámításánál relatív intenzitásokat alkalmaztunk. Legnagyobb területtel megjelenő komponens az Irgacure184 volt. A kaprolakton értékei (mind átlag, mind szórás tekintetében) tízszeres szorzót kaptak annak érdekében, hogy a kioldódó komponensek egy közös ábrán bemutathatóak legyenek. Ennek a komponensnek a területe jelentősen kisebb, mint a másik két komponensé.

\section{Megbeszélés}

A sejtéletképességi vizsgálatok eredményei alapján elmondható, hogy a MED610 anyag a felületnöveléssel párhuzamosan szignifikánsan csökkenti a SAOS-2 sejtek proliferációját, melyet az anyaggal történő közvetlen érintkezés felerősít. Schmelzer és munkatársainak kísérletében [22] a MED610 jelentős negatív hatást mutatott felnőtt bőr epidermális keratinociták, valamint csontvelő eredetű mesenchymális őssejtek életképességére. Közvetett kontaktusban a keratinociták esetében, csökkentette a sejtszámot, valamint a Ki67 proliferációs marker kifejeződését. A csontvelő eredetű őssejtekkel közvetlen kontaktusban sejthalált idézett elő a kaszpáz 3 (CASP3) apoptózis marker indukciója révén [22]. A SAOS-2 sejteknél tapasztalt sejtszámcsökkenésre alapozva feltételezhető, hogy ez esetben is hasonló tényezők játszhatnak szerepet, jóllehet ennek megerősítéséhez további kísérletek szükségesek.

A felületi topográfia szintén fontos szerepet játszik a sejtek letapadásában, valamint hatással van a sejtfunkciók kontrollálására, így például a citoszkeletális szerveződésre, adhézióra, polarizációra, migrációra, proliferációra és differenciációra $[9,20]$ is. Mivel a MED610 felszíne nagy egyenetlenségeket mutat [22], ezen tulajdonsága feltételezhetően szintén hozzájárul a SAOS-2 sejteknél megfigyelt csökkent proliferációs aktivitáshoz.

Hozzá kell tennünk azonban, hogy a felületi topográfia mellett a sejtekkel közvetve érintkező anyag a negyedik napra szintén nagymértékben negatívan befolyásolta a sejtszámot, amely azt jelzi, hogy a megfigyelt hatásokban a MED610-ből kioldódó komponensek is jelentős szerepet játszanak. A felületnövelt mintákon mindhárom vizsgálati napon tapasztalt sejtszámbeli csökkenés megerősíti ezt a feltételezést. A kapott kísérleti eredmények alapján felállított feltételezés szerint a MED610-ből kioldódó toxikus anyagok a nagyobb felület következtében nagyobb mennyiségben vagy gyorsabban oldódnak ki a vizsgált objektumból, ezáltal nagyobb koncentrációban találhatóak meg a sejtek környezetében, melyek potenciálisan negatívan befolyásolhatják a sejtek proliferációját.

A fotopolimer-rendszerek alapvetően három komponensből állnak. Ezek a monomerek, a fotoiniciátorok és az adalékanyagok, például UV-stabilizátorok [6]. Leonhardt és munkatársainak kísérlete alapján a meg nem kötött monomerek a meghatározóak a fotopolimer rendszerek biokompatibilitásában [16]. A kioldódási vizsgá- lat során azonosított komponensek az izobornil-akrilát, hidroxiciklohexil-fenil-keton (Irgacure184) és az $\varepsilon$-kaprolakton voltak. A Stratasys által kiadott anyagbiztonsági adatlap felhívja a figyelmet az izobornil-akrilát lehetséges káros hatásaira, amelynek potenciális kontakt bőrgyulladást okozó hatását több tanulmány során is vizsgálták már [15, 18, 19]. Szájüregi érintkezés során a medián halálos adag patkányokban 4890 mg/kg, míg bőrrel való érintkezéskor nyulakban ez a mennyiség több mint 5000 mg/kg [11]. Az általunk meghatározott többi komponens jelenlétéről tulajdonjogok miatt nem kapunk ezen adatlapban pontos információt, de nagy valószínúséggel az Irgacure184 a MED610 anyagban lévő fotoiniciátor, a kaprolakton pedig az anyagban lévő egyik monomer. Williams és munkatársainak tanulmánya alapján a hidroxiciklohexil-fenil-keton emberi magzati oszteoblasztokra és szarvasmarha kondrocitákra jelentős citotoxikus hatást fejtett ki [27]. Hasonló eredményt kaptak Yamaji és munkatársai emberi monocitákon végzett kísérletükben [28]. A polikaprolaktonnal végzett vizsgálatok eddig nem mutatták ki annak számottevő mérgező hatását [2, 4, 23], ezáltal valószínúleg nincs hatással az általunk tapasztalt életképesség-csökkenésre sem.

Eredményeinket az irodalomban megtalálható vizsgálatokkal összevetve feltételezhetjük, hogy a sejtéletképességi vizsgálatainkban tapasztalt sejtszámcsökkenésre a MED610 felületén kívül hatással lehet az izobornil-akrilát és az Irgacure184 kioldódása, míg a szintén jelen lévő kaprolaktonnak nagy valószínūséggel nincs ilyen negatív hatása.

\section{Konklúzió}

A sejtéletképességi vizsgálatok eredményei alapján elmondható, hogy a MED610 anyag a felületnöveléssel párhuzamosan szignifikánsan csökkenti a SAOS-2 sejtek proliferációját, amelyet az anyaggal történő direkt érintkezés felerősít. Az általunk megfigyelt hatást valószínúleg a MED610-ből kioldódó toxikus anyagok, az izobornil-akrilát és a hidroxiciklohexil-fenil-keton (Irgacure184) okozzák, amelyeknek kioldódó mennyisége a nyomtatott tárgy felületével arányosan növekszik. Ennek klinikai relevanciája az lehet, hogy a MED610-ből nyomtatott fogszabályozó készülékek rendszeres viselése esetén a MED610 befolyásolhatja a szájüregi nyálkahártyát, de ilyen messzemenő következtetések levonására specifikusabb vizsgálatok szükségesek.

A munka a GINOP-2.3.2.-15-2016-00011, GINOP-2.3.2.15-2016-00022 és az ÚNKP-18-2-I-DE-164 projektek segítségével valósult meg. A tanulmány alapjául szolgáló kutatást az Emberi Erőforrások Minisztériuma által meghirdetett Felsőoktatási Intézményi Kiválósági Program (20428-3/2018/FEKUTSTRAT) támogatta, a Debreceni Egyetem biotechnológia tématerületi programja keretében. 


\section{Irodalom}

1. Alifiu-Segbaya F, Varma S, Lieschie GJ, George R: Biocompatibility of Photopolymers in 3D Printing. 3D Print Addit Manuf 2017; 4: 185-191. https://doi.org/10.1089/3dp.2017.0064

2. Bulcao RP, Freitas Fa, Venturini CG, Dallegrave E, Durgante J, GöEthel G, et al: Acute and Subchronic Toxicity Evaluation of Poly ( $\varepsilon$-Caprolactone) Lipid-Core Nanocapsules in Rats. Toxicol Sci 2012; 132: 162-176. https://doi.org/10.1093/toxsci/kfs334

3. Connert t, Zehnder MS, Amato M, Weiger R, Kühl S, Krastil G: Microguided endodontics: A method to achieve minimally invasive access cavity preparation and root canal location in mandibular incisors using a novel computer-guided technique. Int Endod J 2018; 51: 247-255. https://doi.org/10.1111/iej.12809

4. Corrales T, Larraza I, Catalina F, Portolés T, Ramírez-Santillán, Matesanz M, et al: In Vitro Biocompatibility and Antimicrobial Activity of Poly( $\varepsilon$-caprolactone)/Montmorillonite Nanocomposites. Biomacromolecules 2012; 13: 4247-4256. https://doi.org/10.1021/bm301537g

5. Czekanska EM, Stoddart MJ, Richards RG, Hayes JS: In search of an osteoblast cell model for in vitro research. Eur Cell Mater 2012; 24: 1-17. https://doi.org/10.22203/ecm.v024a01

6. DECKER C: Kinetic study and new applications of UV radiation curing. Macromol Rapid Comm 2002; 23: 1067-1093. https://doi.org/10.1002/marc.200290014

7. DoDzıuk H: Applications of 3D printing in healthcare. Kardiochir Torakochirurgia Pol 2016; 13: 283-293. https://doi.org/10.5114/kitp.2016.62625

8. Groth C, Kravitz ND, Jones PE, Graham JW, Redmond WR: Three-dimensional printing technology. $J$ Clin Orthod 2014; 48: 475-485.

9. Hereath HM, Di Silvio L, Evans JR: Osteoblast response to zirconia surfaces with different topographies. Mater Sci Eng C Mater Biol Appl 2015; 57: 363-370. https://doi.org/10.1016/j.msec.2015.07.052

10. http://www.padtinc.com/blog/padt-medical/on-thebiocompatibility-of-polyjet-med610 (2018.12.27.)

11. https://web.archive.org/web/20171011181253 /http://usglobalimages.stratasys.com/Main/Files/MSDS/MED610_ Usage_Terms.pdf?v=635888173072389415 (2019.01.22.)

12. https://web.archive.org/web/20190204083404/ https://www.sys-uk.com/wp-content/uploads/2016/01/MSDSClear-Bio-Compatible-MED610-English-US.pdf (2019.01.17.)

13. https://www.stratasys.com/materials/search/biocompatible (2018.12.26.)

14. https://www.stratasys.com/materials/search/dental-materials $\mathrm{s}(2019.02 .03$.

15. Jáuregui I, Sanchez J, Segurola A, Galán C, Seras Y, Gamboa PM: Allergic contact dermatitis by isobornyl acrylate in glucose monitoring devices: Report of two cases. Contact Dermatitis 2019; 81: 2019-2220. https://doi.org/10.1111/cod.13349

16. Leonhardt S, Klare M, Scheer M, Fischer T, Cordes B, EBLENKAMP M: Biocompatibility of photopolymers for additive manufacturing. CDBME 2016; 2: 113-116. https://doi.org/10.1515/cdbme-2016-0028
17. Macdonald NP, Zhu F, Hall CJ, Reboud J, Crosier PS, Patton Ee, et al: Assessment of biocompatibility of 3D printed photopolymers using zebrafish embryo toxicity assays. Lab Chip 2016; 16: 291-297. https://doi.org/10.1039/C5LC01374G

18. Mine $Y$, Urakami T, Matsuura D: Allergic contact dermatitis caused by isobornyl acrylate when using the FreeStyle ${ }^{\circledR}$ Libre. J Diabes Investig 2019; 10: 1382-1384. https://doi.org/10.1111/jdi.13023

19. Oppel E, Högg C, Summer B, Rueff F, Reichl FX, Kamann S: Isobornyl acrylate contained in the insulin patch pump OmniPod as the cause of severe allergic contact dermatitis. Contact Dermatitis 2018 79: 178-180. https://doi.org/10.1111/cod.13017

20. Ross C, Pandav SS, Li YQ, Nguyen DQ, Beirne S, Wallace GG, et al: Determination of Bleb Capsule Porosity With an Experimental Glaucoma Drainage Device and Measurement System. JAMA Ophthalmol 2015; 133: 549-554. https://doi.org/10.1001/jamaophthalmol.2015.30

21. Saldana L, Bensiamar F, Boré A, Vilaboa N: In search of representative models of human bone-forming cells for cytocompatibility studies. Acta Biomater 2011; 12: 4210-4221. https://doi.org/10.1016/j.actbio.2011.07.019

22. Schmelzer E, Over P, Gridelli B, Gerlach JC: Response of Primary Human Bone Marrow Mesenchymal Stromal Cells and Dermal Keratinocytes to Thermal Printer Materials In Vitro. J Med Biol Eng 2016; 36: 153-167. https://doi.org/10.1007/s40846-016-0118-z

23. Souza NLGD, Munk M, Brandao HM, de Oliveira LFC: Cytotoxicity and Compatibility of Polymeric Blend: Evaluation of the Cytotoxicity in Fibroblast Bovine Cells and Compatibility of Poly ( $\varepsilon$-Caprolactone)/Poly(Methyl Methacrylate-co-Butyl Methacrylate) Blend Films. Polym-Plast Technol 2017; 56: 1076-1083. https://doi.org/10.1080/03602559.2016.1253735

24. Strbac GD, Schnappauf A, Giannis K, Berri MH, Moritz A, Ulm C: Guided Autotransplantation of Teeth: A Novel Method Using Virtually Planned 3-dimensional Templates. $J$ Endod 2016; 42: 1844-1850. https://doi.org/10.1016/j.joen.2016.08.021

25. Szaloki M, Javadi H, Khandan S, Youssef AS, Gáll J, Hegedüs Cs: 3D nyomtatható biokompatibilis modell alapanyagok polimerizációs tulajdonságainak vizsgálata. Fogorvosi Szemle 2019; 112: 70-76. https://doi.org/10.33891/FSZ.112.3.70-76

26. Walsh ME, Ostrinskaya A, Sorensen MT, Kong DS, Carr Pa: 3D-Printable Materials for Microbial Liquid Culture. 3D Print Addit Manuf 2016; 3: 113-118. https://doi.org/10.1089/3dp.2016.0007

27. Williams CG, Malik AN, Kim TK, Manson PN, Elisseeff JH: Variable cytocompatibility of six cell lines with photoinitiators used for polymerizing hydrogels and cell encapsulation. Biomaterials 2005; 26: 1211-1218. https://doi.org/10.1016/j.biomaterials.2004.04.024

28. Yamajl K, Kawasaki Y, Yoshitome K, Matsunaga H, Sendo T: Quantitation and human monocyte cytotoxicity of the polymerization agent 1-hydroxycyclohexyl phenyl ketone (Irgacure 184) from three brands of aqueous injection solution. Biol Pharm Bull 2012; 35: 1821-1825. https://doi.org/10.1248/bpb.b12-00210 


\author{
Youssef A, Tóth F, Hegedüs Cs, Szalókı M
}

\title{
Qualitative analysis of monomers released from 3D printable MED610 polymer and their effect on cells
}

Thanks to the dynamically evolving 3D printing technology, the use of 3D printing is becoming more and more widely used besides the industrial areas by medical sciences as well. The most commonly used materials in dentistry are polymers, and their biocompatibility is a key question when used in oral environments. Our aim was to identify the components released from the biocompatible MED610 (Stratasys, USA) polymer samples and to monitor their effects on bonederived cells. During the research, the biocompatibility of the polymer was investigated, and its effect on osteosarcoma (SAOS-2) cell proliferation was observed. In the series of experiments objects of various sizes, shapes and surface area sizes were printed of MED610 polymer with Objet 30 Orthojet (Stratasys, USA) printer and the objects were surface treated according to the manufacturer's instructions. Printed samples were exposed directly or indirectly to Sarcoma Osteogenic-2 (SAOS-2) cells during the experiments. The dissolution assay of MED610 was performed for 7 days using 11 samples in methanol and analyzed by gas chromatography - mass spectrometry coupled method (GC-MS). The components were identified by MS search based on MS spectra. As a result, several components were identified, three in relatively large amounts. These were isobornyl acrylate, hydroxycyclohexyl-phenyl-ketone and caprolactone. The effect of the different dimensions of the MED610 polymer on the proliferation of SAOS-2 cells was studied by alamarBlue assay (Thermo Fisher Scientific, USA). Based on the results of cell viability assays, MED610 significantly decreases SAOS-2 cell proliferation in parallel with surface increment, which is enhanced by direct exposure to the substance. The effect we are observing is probably caused by the toxic substances liberated from MED610. In case of a bigger surface area, the substances are released more rapidly from MED610 and thus are present in higher concentrations in the cellular environment.

Keywords: MED610, biocompatibility, 3D printing, SAOS-2, alamarBlue 